medRxiv preprint doi: https://doi.org/10.1101/2021.09.28.21264264; this version posted September 29, 2021. The copyright holder for this

preprint (which was not certified by peer review) is the author/funder, who has granted medRxiv a license to display the preprint in perpetuity.

It is made available under a CC-BY-NC-ND 4.0 International license.

\title{
A Multidisciplinary Prematurity Research Cohort Study
}

3 Author list:

Molly J. Stout ${ }^{1}$, Jessica Chubiz², Nandini Raghuraman², Peinan Zhao ${ }^{2}$, Methodius G. Tuuli ${ }^{3}$, Lihong V.

Wang $^{4}$, Alison G. Cahill ${ }^{5}$, Phillip S. Cuculich ${ }^{6}$, Yong Wang ${ }^{2}$, Emily S. Jungheim ${ }^{7}$, Erik D. Herzog ${ }^{8}$, Justin

Fay $^{9}$, Alan L. Schwartz ${ }^{10}$, George A. Macones ${ }^{5}$, and Sarah K. England ${ }^{2}$

\section{Affiliations:}

${ }^{1}$ Department of Obstetrics and Gynecology, University of Michigan, Ann Arbor, Michigan, USA

${ }^{2}$ Department of Obstetrics and Gynecology, Washington University in St. Louis, St. Louis, Missouri, USA

${ }^{3}$ Department of Obstetrics and Gynecology, Brown University, Rhode Island, USA

${ }^{4}$ Department of Medical Engineering, California Institute of Technology, Pasadena, California, USA

${ }^{5}$ Department of Women's Health, University of Texas at Austin, Austin, Texas, USA

${ }^{6}$ Department of Internal Medicine, Washington University in St. Louis, St. Louis, Missouri, USA

${ }^{7}$ Department of Obstetrics and Gynecology, Northwestern University, Chicago, Illinois, USA

${ }^{8}$ Department of Biology, Washington University in St. Louis, St. Louis, Missouri, USA

${ }^{9}$ Department of Biology, University of Rochester, Rochester, New York, USA

${ }^{10}$ Department of Pediatrics, Washington University in St. Louis, St. Louis, Missouri, USA

*To whom correspondence should be addressed: Department of Obstetrics and Gynecology,

Washington University in St. Louis School of Medicine, 425 South Euclid Avenue, Campus Box 8064, St. 
medRxiv preprint doi: https://doi.org/10.1101/2021.09.28.21264264; this version posted September 29, 2021. The copyright holder for this

preprint (which was not certified by peer review) is the author/funder, who has granted medRxiv a license to display the preprint in perpetuity.

It is made available under a CC-BY-NC-ND 4.0 International license .

\section{ABSTRACT}

\section{Background}

Worldwide, $10 \%$ of babies are born preterm, defined as a live birth before 37 weeks of gestation. Preterm birth is the leading cause of neonatal death, and survivors face lifelong risks of adverse outcomes. New approaches with large sample sizes are needed to identify strategies to predict and prevent preterm birth. The primary aims of the Washington University Prematurity Research Cohort Study were to conduct three prospective projects addressing possible causes of preterm birth and provide data and samples for future research.

\section{Study Design}

Pregnant patients were recruited into the cohort between January 2017 and January 2020. Consenting patients were enrolled into the study before 20 weeks' gestation and followed through delivery. Participants completed demographic and lifestyle surveys; provided maternal blood, placenta samples, and cord blood; and participated in up to three projects focused on underlying physiology of preterm birth: cervical imaging (Project 1), circadian rhythms (Project 2), and uterine magnetic resonance imaging and electromyometrial imaging (Project 3).

\section{Results}

A total of 1260 participants were enrolled and delivered during the study period. Of the participants, 706 (56\%) were Black/African American, 494 (39\%) were nulliparous, and 185 (15\%) had a previous preterm birth. Of the 1260 participants, 1220 (97\%) delivered a live infant. Of the 1220 with a live birth, $163(14.1 \%)$ had preterm birth, of which $74(6.1 \%)$ were spontaneous preterm birth. Of the 1220 participants with a live birth, 841 participated in cervical imaging, 1047 contributed data and/or samples on circadian rhythms, and 39 underwent uterine magnetic resonance imaging. Of the 39, 25 underwent electromyometrial imaging.

\section{Conclusion}


medRxiv preprint doi: https://doi.org/10.1101/2021.09.28.21264264; this version posted September 29, 2021. The copyright holder for this preprint (which was not certified by peer review) is the author/funder, who has granted medRxiv a license to display the preprint in perpetuity. It is made available under a CC-BY-NC-ND 4.0 International license .

53 We demonstrate feasibility of recruiting and retaining a diverse cohort in a complex prospective, 54 longitudinal study throughout pregnancy. The extensive clinical, imaging, survey, and biologic data 55 obtained will be used to explore cervical, uterine, and endocrine physiology of preterm birth and can be 56 used to develop novel approaches to predict and prevent preterm birth.

57

58 
medRxiv preprint doi: https://doi.org/10.1101/2021.09.28.21264264; this version posted September 29, 2021. The copyright holder for this

preprint (which was not certified by peer review) is the author/funder, who has granted medRxiv a license to display the preprint in perpetuity.

It is made available under a CC-BY-NC-ND 4.0 International license .

\section{INTRODUCTION}

Preterm birth, defined as delivery before 37 weeks' gestation, affects 1 in 10 babies worldwide and is the leading cause of infant mortality (1). Neonates who survive are at increased risk of lifelong adverse health outcomes (2-4). This problem is especially notable in St. Louis, Missouri, USA, where $13 \%$ of babies are born preterm and racial disparities are pronounced; $11 \%$ of white women and over $17 \%$ of Black women deliver preterm (5). Despite decades of research, we have limited understanding of the causes of preterm birth and few strategies to predict or prevent this adverse pregnancy outcome.

In 2013, Lackritz and colleagues argued that preventing preterm birth would require rigorous research to identify the underlying biological and social determinants. Additionally, they argued for development of new tools to monitor pregnancy and identify those at highest risk of preterm birth (6). To that end, we formed the Washington University in St. Louis Prematurity Research Center in 2014 with funding from the March of Dimes Foundation, St. Louis Children's Hospital, Barnes-Jewish Hospital, and Washington University in St. Louis. The Prematurity Research Center united a multidisciplinary group of investigators including obstetricians, engineers, circadian biologists, and cardiac electrophysiologists to approach preterm birth in novel ways.

The three primary projects of the Prematurity Research Center focused on identifying anatomic, physiologic, and behavioral features that are associated with and can be used to predict preterm birth. The first project, Cervical Imaging, used high-speed functional photoacoustic endoscopy to quantify anatomic changes during cervical remodeling $(7,8)$. The second project, Circadian Rhythms, used actigraphy, hormone secretion patterns, and surveys to determine whether disruption in circadian rhythms is a risk factor for preterm birth (5). The third project, Uterine Electrical Activity, developed a novel imaging system to noninvasively map electrical activity of the uterus during labor contractions (9-12).

To gather data for these projects, we initiated the Prematurity Research Cohort Study to longitudinally follow over 1000 participants from early in pregnancy through delivery. The purpose of this report is to 
medRxiv preprint doi: https://doi.org/10.1101/2021.09.28.21264264; this version posted September 29, 2021. The copyright holder for this

preprint (which was not certified by peer review) is the author/funder, who has granted medRxiv a license to display the preprint in perpetuity.

It is made available under a CC-BY-NC-ND 4.0 International license .

87 describe the demographics of this cohort and the types of data and biospecimens obtained. In addition, 88 we address the feasibility of conducting a multidisciplinary study in which a diverse cohort of pregnant patients are followed throughout pregnancy.

\section{METHODS}

The Prematurity Research Cohort Study was a prospective, Iongitudinal cohort study performed at Washington University in St. Louis Medical Center between January 2017 and January 2020. Participants were enrolled in the first or early second trimester and followed through delivery. The study received ethical approval from the Washington University in St. Louis Institutional Review Board. All participants provided written informed consent for collection and use of clinical, biospecimen, imaging, or questionnaire data.

\section{Inclusion and exclusion criteria}

Women were approached for enrollment if they had a singleton pregnancy $\leq 20$ weeks' gestation (determined by best obstetric estimate including last menstrual period or earliest ultrasound dating available) and met the following inclusion criteria: plan to deliver at Barnes-Jewish Hospital, 18 years of age or older, and English speaking. Patients were not eligible if they were incarcerated. Additionally, patients who conceived via in vitro fertilization were not enrolled. If a major fetal anomaly was diagnosed during pregnancy, it was reviewed by a maternal-fetal medicine attending physician. If the anomaly affected gestational age at delivery, the patient was withdrawn from the study.

\section{Research staff}

A large research staff was assembled to support all projects by enrolling participants, performing longitudinal follow-up, scheduling appointments, coordinating research study visits, contacting study participants who missed study visits, collecting data, and managing specimen collection. The research staff comprised one research coordinator, three registered nurses, one sonographer, three research associates, a research lab coordinator, and one research lab assistant. Additionally, eight staff members 
medRxiv preprint doi: https://doi.org/10.1101/2021.09.28.21264264; this version posted September 29, 2021. The copyright holder for this

preprint (which was not certified by peer review) is the author/funder, who has granted medRxiv a license to display the preprint in perpetuity.

It is made available under a CC-BY-NC-ND 4.0 International license .

114 delivery for multiple studies. This team was available 24 hours a day, seven days a week, 365 days a year,

115 and each spent approximately $25 \%$ of their effort on the three Prematurity Research Center projects. In 116 addition, two statisticians provided analytic support, and a scientific editor reviewed all scientific 117 presentations and reports.

\section{Participant recruitment and longitudinal follow-up}

Patients were approached for enrollment at their initial prenatal appointment at two obstetric clinics on the Washington University Medical Campus. One clinic primarily serves patients with public health insurance, 122 and the other primarily serves patients with private health insurance. All potential participants were offered enrollment into projects 1 and 2. Participants were seen at study visits longitudinally throughout pregnancy and at delivery. Study visits were scheduled to obtain data and samples in each of the three trimesters

(Figure 1). All study visits were aligned as much as possible with routine obstetric care to minimize inconvenience to the participants. When additional visits were needed outside of routine medical care visits, appointments were scheduled during routine business hours at the participant's convenience. For follow-up and retention, participants were contacted by phone and/or text messages to remind them of study visits, and transportation was arranged, if needed, to facilitate study participation. Study personnel were available via phone and text during business hours to answer study-related questions.

\section{Data and specimen collection}

133 The timing and sources of data and specimens collected are illustrated in Figure 1.

135 Case report form. A comprehensive case report form was used to collect data from electronic medical 136 records on the index pregnancy, previous pregnancies, maternal demographics and medical history, labor 137 and delivery, neonatal outcomes until discharge from hospital, and maternal postpartum visits. Obstetric research personnel including research coordinators and research nurses were trained by a Research Nurse coordinator on abstracting clinical data. For quality assurance, the Research Nurse coordinator 
medRxiv preprint doi: https://doi.org/10.1101/2021.09.28.21264264; this version posted September 29, 2021. The copyright holder for this preprint (which was not certified by peer review) is the author/funder, who has granted medRxiv a license to display the preprint in perpetuity.

It is made available under a CC-BY-NC-ND 4.0 International license .

141 medical record releases were requested to obtain delivery data. The case report form used to collect

142 pregnancy outcome data is shown in Table 1.

Table 1: Case report form for pregnancy
outcomes
\begin{tabular}{|l|l|}
\hline Date of delivery \\
\hline Time of delivery \\
Preterm birth (<37 weeks) \\
\hline Spontaneous preterm birth \\
If spontaneous preterm birth, presentation \\
Preterm premature rupture of membranes \\
Dilation \\
Preterm premature rupture of membranes + dilation \\
Other (specify) \\
Unknown/not available \\
Tocolytic medication during pregnancy \\
None \\
Magnesium \\
Indocin \\
Terbutaline \\
Nifedipine \\
Multiple \\
Unknown/not available \\
Gestational age at delivery \\
If term birth ( $\geq 37$ weeks), presentation \\
Premature rupture of membranes \\
Dilation \\
Premature rupture of membranes + dilation \\
Induction \\
Other (specify) \\
Unknown/not available \\
\hline Was magnesium sulfate administered? \\
Clinical chorioamnionitis \\
Intrapartum antibiotics \\
Preterm premature rupture of membranes prophylaxis \\
Group B streptococcus prophylaxis \\
Chorioamnionitis \\
Other \\
Unknown/not available \\
\hline Type of delivery \\
Spontaneous vaginal \\
Operative vaginal \\
C-section \\
Unknown/not available \\
\hline
\end{tabular}

144 Project 1-Cervical Imaging. A research nurse collected swabs from three areas of the vagina (posterior 145 fornix, mid-vagina, and introitus) via speculum exam immediately before performing cervical imaging. 146 Swabs were refrigerated at $4^{\circ} \mathrm{C}$ immediately after collection and transferred to $-80^{\circ} \mathrm{C}$ within 8 hours. After 147 swab collection, novel cervical photoendoscopy devices were used to obtain cervical imaging data 148 transvaginally $(7,8)$. Additionally, standard transvaginal ultrasound images of the cervix were obtained and 149 used to measure cervical length at each imaging session. Vaginal swabs were collected and cervical 
medRxiv preprint doi: https://doi.org/10.1101/2021.09.28.21264264; this version posted September 29, 2021. The copyright holder for this

preprint (which was not certified by peer review) is the author/funder, who has granted medRxiv a license to display the preprint in perpetuity.

It is made available under a CC-BY-NC-ND 4.0 International license .

150 imaging was performed once in each trimester. A subset of participants underwent sampling and imaging

151 up to three additional times, with a minimum of four weeks between sampling/imaging sessions.

152

153 Project 2-Circadian Rhythms. All participants completed validated questionnaires about sleep habits and

154 other lifestyle measures (Figure 1 and Supplemental Table 1). Participants were given the option of

155 completing surveys via an online link or taking the questionnaires home and returning them to research

156 staff at their next obstetric or research study visit. Research staff called or texted participants to remind

157 them to bring completed surveys to subsequent study visits. Patients with incomplete third trimester

158 surveys were offered the opportunity to complete the surveys on an iPad during admission for delivery.

160 Participants provided salivary samples every four hours during one 24-hour period each trimester, with

161 collection starting at 18:00 hours. Participants received supplies to collect saliva (Salimetrics, United

162 Kingdom) at home. Research staff called or texted participants to remind them of instructions for collecting

163 saliva and to bring their samples to their next visit. Participants were instructed to place samples in the

164 freezer until bringing them to the research staff. Once received, the samples were timestamped, stored at

$165-80{ }^{\circ} \mathrm{C}$, and processed to measure melatonin and cortisol concentrations by ELISA (Salimetrics Melatonin

166 ELISA kit and Salimetrics Cortisol ELISA kit) in a research laboratory.

167

168 Participants wore wrist actigraphy devices (Motionwatch8, CamNTech, United Kingdom) for two-week time 169 periods during their first, second, and third trimesters, as outlined by Martin-Fairey et al. (5). The actigraphy 170 devices captured minute-level movement and light exposure and remained charged for approximately 90 171 days, ensuring continuous data collection. Research staff called, texted, or emailed participants to remind 172 them to bring the devices back to the next study visit after the two-week data capture period, or they 173 arranged a courier service for retrieval. If the device was not returned, self-addressed, stamped envelopes 174 were mailed to participants' addresses with a letter requesting return of the device and offering a $\$ 20$ gift 175 card if they did so. 
medRxiv preprint doi: https://doi.org/10.1101/2021.09.28.21264264; this version posted September 29, 2021. The copyright holder for this

preprint (which was not certified by peer review) is the author/funder, who has granted medRxiv a license to display the preprint in perpetuity.

It is made available under a CC-BY-NC-ND 4.0 International license .

177 Project 3-Uterine Electrical Activity. Sixty-three participants from the total cohort were enrolled to

178 participate in Project 3. Participants included those at low risk for preterm birth (defined as a normal cervical

179 length at anatomy screen and no history of spontaneous preterm birth) and those at high risk for preterm

180 birth (defined as a previous spontaneous preterm birth less than 35 weeks or a cervical length less than 2

$181 \mathrm{~cm}$ during the index pregnancy). Those in the low-risk group underwent uterine magnetic resonance

182 imaging (MRI) at 37 weeks' gestation, and those in the high-risk group underwent MRI at 24, 28, and 32

183 weeks' gestation. Once patients presented for induction or in spontaneous labor and were in active labor

184 (defined as greater than $4 \mathrm{~cm}$ dilation and regular contractions), body surface potential mapping was

185 performed for approximately one hour. The combined uterine MRI and body surface potential mapping

186 resulted in data used for electromyometrial imaging (EMMI), which has been described elsewhere (9-12).

187 MRI was performed in a 3T Siemens Prisma/Vida whole-body MRI Scanner with a radial volume

188 interpolated breath-hold examination fast T1-weighted sequence. Patients who also consented to be a part

189 of the cervical imaging project had MRI performed on the same day.

190

191 Biological specimens

192 Maternal blood serum and plasma samples were collected throughout pregnancy during routine clinical

193 lab visits during business hours (or drawn by research staff if labs were done elsewhere or missed),

194 refrigerated at $4{ }^{\circ} \mathrm{C}$, and centrifuged at $1620 \times \mathrm{g}$ for 5 minutes at $4{ }^{\circ} \mathrm{C}$ within 12 hours of collection. Aliquots

$195(1 \mathrm{~mL})$ were stored at $-80^{\circ} \mathrm{C}$. Cord blood serum and plasma were collected at delivery and processed in

196 the same manner as the maternal blood. In cases in which cord blood was not collected, infant buccal

197 swabs were collected with the mother's consent. At least 30 minutes after the infant was fed, a swab was

198 rubbed firmly against the inside cheek and lower and upper lip for one minute and stored at room

199 temperature. Four sets of placenta specimens $(1 \times 3 \mathrm{~cm})$ were collected at delivery from each of four sites:

200 chorionic amnion, basal plate, villous tissue, and subchorion. All placental samples were snap frozen in

201 liquid nitrogen and stored at $-80^{\circ} \mathrm{C}$. Amniotic fluid was collected at the time of delivery from 56 patients

202 who underwent unlabored, intact cesarean section. Fluid was centrifuged at $1620 \times \mathrm{g}$ for 5 minutes at $4{ }^{\circ} \mathrm{C}$

203 and then stored at $-80^{\circ} \mathrm{C}$. 
medRxiv preprint doi: https://doi.org/10.1101/2021.09.28.21264264; this version posted September 29, 2021. The copyright holder for this

preprint (which was not certified by peer review) is the author/funder, who has granted medRxiv a license to display the preprint in perpetuity.

It is made available under a CC-BY-NC-ND 4.0 International license .

\section{Participant incentives}

All participants received gift cards for completing study visits. Participants received $\$ 25$ gift cards each

trimester for completing the combination of surveys, wrist-worn actigraphy, and 24-hour saliva collection.

Participants also received $\$ 25$ gift cards for each completed transvaginal imaging exam, $\$ 50$ gift cards for

each MRI, and a $\$ 50$ gift card at delivery if the majority of study procedures were completed. Participants

also received a small non-monetary gift (e.g., pen, reusable bag, children's book) at the completion of each

study visit and at delivery. For participants without reliable transportation, taxis or Uber Health cars were

arranged for transport to and from study appointments at no cost to the participant. For prolonged study

visits that spanned a mealtime (typically $3+$ hours; combining clinical appointment with transvaginal

214 imaging and MRI), a meal was provided to the participant. Granola bars and other small snacks were available to participants for shorter study visits. Crayons and coloring pages were offered to the children of participants who attended study visits.

\section{RESULTS}

\section{Participant attrition and demographics}

A flow diagram of participant enrollment and outcomes is provided in Figure 2. We screened 7478 patients for potential enrollment; 2718 (36.3\%) met inclusion criteria (<20 weeks' gestation, age >18 years, English speaking) and were approached. Among those approached, 1523 (56.0\%) gave consent and enrolled. Of the enrolled participants, 190 (12.5\%) were lost to follow-up and $73(4.8 \%)$ withdrew and were not included in the final analyses. We have complete clinical and outcome data on 1260 (82.7\%) participants.

Demographic characteristics of the 1260 participants are described in Table 2 . The majority of participants reported being employed (70.8\%), Black/African American (56.0\%), and single $(61.2 \%)$. More than onethird of participants (36.9\%) reported an annual income $<\$ 25,000,44.8 \%$ had public insurance or were uninsured, and $53.9 \%$ had private insurance. 
medRxiv preprint doi: https://doi.org/10.1101/2021.09.28.21264264; this version posted September 29, 2021. The copyright holder for this preprint (which was not certified by peer review) is the author/funder, who has granted medRxiv a license to display the preprint in perpetuity.

It is made available under a CC-BY-NC-ND 4.0 International license .

Table 2: Demographic data of study participants

\begin{tabular}{|c|c|}
\hline Total enrolled with outcome data & $N=1260$ \\
\hline \multicolumn{2}{|l|}{ Education } \\
\hline Less than $12^{\text {th }}$ grade & $(6.1 \%)$ \\
\hline High school degree/GED & $583(46.3 \%)$ \\
\hline College degree (4 years) & $179 \quad(14.2 \%)$ \\
\hline Graduate degree & $250(19.8 \%)$ \\
\hline Missing/Unknown & $171(13.6 \%)$ \\
\hline \multicolumn{2}{|l|}{ Marital status } \\
\hline Single & $771 \quad(61.2 \%)$ \\
\hline Married & $460 \quad(36.5 \%)$ \\
\hline Other & $29 \quad(2.3 \%)$ \\
\hline \multicolumn{2}{|l|}{ Employment } \\
\hline Yes & $892 \quad(70.8 \%)$ \\
\hline No & $273(21.7 \%)$ \\
\hline Student & $39 \quad(3.1 \%)$ \\
\hline Missing/Unknown & $56 \quad(4.4 \%)$ \\
\hline \multicolumn{2}{|l|}{ Annual income (T1) } \\
\hline Government Assistance & $92 \quad(7.3 \%)$ \\
\hline$<\$ 25,000$ & $465(36.9 \%)$ \\
\hline$\$ 25,000-\$ 74,999$ & $265(21.0 \%)$ \\
\hline$\$ 75,000-\$ 124,999$ & $155(12.3 \%)$ \\
\hline$\geq \$ 125,000$ & $160 \quad(12.7 \%)$ \\
\hline Missing/Unknown & $123(12.7 \%)$ \\
\hline \multicolumn{2}{|l|}{ Insurance } \\
\hline Medicaid & $410(32.5 \%)$ \\
\hline Medicare & $21 \quad(1.7 \%)$ \\
\hline Individual/Group Health Insurance & $679(53.9 \%)$ \\
\hline VA/Military & $12 \quad(1.0 \%)$ \\
\hline Uninsured & $134 \quad(10.6 \%)$ \\
\hline Missing/Unknown & $4 \quad(0.3 \%)$ \\
\hline \multicolumn{2}{|l|}{ Race } \\
\hline Black or African-American & $706 \quad(56.0 \%)$ \\
\hline White & $501 \quad(39.8 \%)$ \\
\hline Other & $53 \quad(4.2 \%)$ \\
\hline \multicolumn{2}{|l|}{ Ethnicity } \\
\hline Non-Hispanic & $1213(96.3 \%)$ \\
\hline Hispanic & $\begin{array}{ll}36 & (2.9 \%) \\
\end{array}$ \\
\hline Unknown & $11(0.9 \%)$ \\
\hline English first language & $1251(99.3 \%)$ \\
\hline
\end{tabular}

\section{Pregnancy characteristics and outcomes}

234 Table 3 demonstrates maternal and pregnancy characteristics in our cohort. The majority $(n=766,60.8 \%)$ 235 were multiparous, and $185(14.7 \%)$ had a history of preterm birth. The most common medical 236 complications among these participants was asthma and chronic hypertension. The most common 237 previous pregnancy complications were gestational hypertension/preeclampsia and intrauterine growth 238 restriction (Table 3).

240 Table 4 describes pregnancy and neonatal outcomes in the 1220 participants who delivered a live birth. 241 Induction of labor was performed in 529 (43.3\%) participants, and 368 (30.2\%) were delivered via 
medRxiv preprint doi: https://doi.org/10.1101/2021.09.28.21264264; this version posted September 29, 2021. The copyright holder for this preprint (which was not certified by peer review) is the author/funder, who has granted medRxiv a license to display the preprint in perpetuity.

It is made available under a CC-BY-NC-ND 4.0 International license .

242 cesarean section. In the cohort, there were 1220 (96.8\%) live births, 23 stillbirths $\geq 20$ weeks, and 17 243 pregnancy losses <20 weeks. Among the 1220 participants with a live birth, $1057(86.6 \%)$ delivered at 244 term and $163(13.4 \%)$ delivered preterm (<37 weeks). Of the live-born neonates, $145(11.9 \%)$ required 245 neonatal intensive care unit admission, $145(11.9 \%)$ had low birthweight $(<2500 \mathrm{~g})$, and $153(13.1 \%)$ were 246 small for gestational age, defined as birthweight $<10^{\text {th }}$ percentile for gestational age.

Table 3: Maternal and pregnancy characteristics

\begin{tabular}{|c|c|}
\hline \multicolumn{2}{|l|}{ Gravidity } \\
\hline Gravida, median (IQR) & $(1,4)$ \\
\hline \multicolumn{2}{|l|}{ Parity } \\
\hline Nulliparous & $494 \quad(39.2 \%)$ \\
\hline Multiparous & $766 \quad(60.8 \%)$ \\
\hline \multicolumn{2}{|l|}{ History of preterm birth } \\
\hline Indicated & $10 \quad(0.8 \%)$ \\
\hline Spontaneous & $175(13.9 \%)$ \\
\hline 24-33 6/7 weeks & $107 \quad(8.5 \%)$ \\
\hline $34-36$ 6/7 weeks & $68 \quad(5.4 \%)$ \\
\hline \multicolumn{2}{|c|}{ History of pregnancy and medical complications } \\
\hline Asthma & $248(19.7 \%)$ \\
\hline Gestational hypertension/Preeclampsia & $214(17.0 \%)$ \\
\hline Chronic hypertension & $144(11.4 \%)$ \\
\hline Diabetes & $71 \quad(5.6 \%)$ \\
\hline Intrauterine growth restriction & $60 \quad(4.8 \%)$ \\
\hline Thyroid disease & $57 \quad(4.5 \%)$ \\
\hline Anomaly & $47 \quad(3.7 \%)$ \\
\hline Heart disease & $37 \quad(2.9 \%)$ \\
\hline Renal disease & $29 \quad(2.3 \%)$ \\
\hline Polyhydramnios & $22 \quad(1.7 \%)$ \\
\hline Oligohydramnios & $10 \quad(0.8 \%)$ \\
\hline Lupus & $6 \quad(0.5 \%)$ \\
\hline
\end{tabular}


medRxiv preprint doi: https://doi.org/10.1101/2021.09.28.21264264; this version posted September 29, 2021. The copyright holder for this preprint (which was not certified by peer review) is the author/funder, who has granted medRxiv a license to display the preprint in perpetuity.

It is made available under a CC-BY-NC-ND 4.0 International license .

250 Table 4: Pregnancy and neonatal outcomes

\begin{tabular}{|c|c|}
\hline \multicolumn{2}{|l|}{ Birth outcome } \\
\hline Live birth & $1220(96.8 \%)$ \\
\hline Loss, $<20$ weeks & $17(1.3 \%)$ \\
\hline Loss, $20+$ weeks & $23(1.8 \%)$ \\
\hline \multicolumn{2}{|l|}{ Gestational age at birth } \\
\hline$<24$ weeks & $3(0.2 \%)$ \\
\hline 24 weeks-31 weeks 6 days & $32(2.6 \%)$ \\
\hline 32 weeks-36 weeks 6 days & $128(10.5 \%)$ \\
\hline $37+$ weeks & $1057(86.6 \%)$ \\
\hline \multicolumn{2}{|l|}{ Preterm Birth } \\
\hline Induced & $89(7.3 \%)$ \\
\hline Spontaneous & $74 \quad(6.8 \%)$ \\
\hline$<24$ weeks & $2(.002 \%)$ \\
\hline $24-33$ weeks 6 days & $22(1.8 \%)$ \\
\hline 34-36 weeks 6 days & $50 \quad(4.1 \%)$ \\
\hline \multicolumn{2}{|l|}{ Delivery method } \\
\hline Vaginal & $806(66.0 \%)$ \\
\hline Operative vaginal & $46 \quad(3.8 \%)$ \\
\hline Cesarean section & $368(30.2 \%)$ \\
\hline \multicolumn{2}{|l|}{ Reason for induction $(\mathrm{N}=529)^{*}$} \\
\hline Oligohydramnios & $6(1.1 \%)$ \\
\hline PROM & $8(1.5 \%)$ \\
\hline PPROM & $7(1.3 \%)$ \\
\hline Preeclampsia/eclampsia & $59(11.2 \%)$ \\
\hline Comorbidity at 39 weeks & $35 \quad(6.6 \%)$ \\
\hline Elective & $236(44.6 \%)$ \\
\hline Non-reassuring antenatal testing & $40(7.6 \%)$ \\
\hline Gestational Diabetes & $16 \quad(3.0 \%)$ \\
\hline Postdates & $64(12.1 \%)$ \\
\hline Intrauterine growth restriction & $46 \quad(8.7 \%)$ \\
\hline Macrosomia & $2(0.4 \%)$ \\
\hline polyhydramnios & $4 \quad(0.8 \%)$ \\
\hline Other & $76(14.4 \%)$ \\
\hline \multicolumn{2}{|l|}{ Neonatal Sex } \\
\hline Female & $581(47.6 \%)$ \\
\hline Male & $639(52.4 \%)$ \\
\hline \multicolumn{2}{|l|}{ Apgar score at 1 minute } \\
\hline $0-3$ & $59(4.8 \%)$ \\
\hline 4-6 & $83 \quad(6.8 \%)$ \\
\hline $7-10$ & $1053(86.3 \%)$ \\
\hline \multicolumn{2}{|l|}{ Apgar score at 5 minutes } \\
\hline $0-3$ & $8(0.7 \%)$ \\
\hline $4-6$ & $40 \quad(3.3 \%)$ \\
\hline $7-10$ & $1163(95.3 \%)$ \\
\hline \multicolumn{2}{|l|}{ NICU information } \\
\hline NICU admission & $145(11.9 \%)$ \\
\hline Length of NICU stay in days & $8(4,21)$ \\
\hline \multicolumn{2}{|l|}{ Neonatal health outcomes } \\
\hline Low birth weight (<2500 grams) & $145(11.9 \%)$ \\
\hline Small, for gestational age $\left(<10^{\text {th }}\right.$ percentile $)$ & $153(13.1 \%)$ \\
\hline Arterial umbilical cord $\mathrm{pH}$ & $7.26(7.22,7.31)$ \\
\hline Newborn death within 28 days & $8(0.7 \%)$ \\
\hline
\end{tabular}

*The percentage of reason for induction is calculated according to the total number of inductions. Some participants had more than one reason for induction.

Data represent $\mathrm{n}(\%)$ or median (interquartile range). 
medRxiv preprint doi: https://doi.org/10.1101/2021.09.28.21264264; this version posted September 29, 2021. The copyright holder for this preprint (which was not certified by peer review) is the author/funder, who has granted medRxiv a license to display the preprint in perpetuity.

It is made available under a CC-BY-NC-ND 4.0 International license .

\section{Data and specimen collection associated with study procedures}

254 Collectively, study participants attended 6135 study visits, which included 1892 cervical imaging exams, 25539 uterine MRIs, 2239 actigraphy recordings, 28,240 lifestyle surveys, and over 12,000 biological 256 specimens (see Table 5). Fewer participants provided saliva samples in the first trimester than in the 257 second and third trimesters. Conversely, more participants completed lifestyle surveys and provided 258 actigraphy data in the first trimester than in the second and third trimesters. More patients underwent 259 transvaginal imaging, which required additional scheduling after consent, in the first trimester than in the 260 second and third trimesters.

Table 5: Sample and survey numbers from participants with live births

\begin{tabular}{|c|c|c|c|c|}
\hline Samples and Data Collected & $\begin{array}{l}\text { First Study } \\
\text { Visit }\end{array}$ & $\begin{array}{l}\text { Second Study } \\
\text { Visit }\end{array}$ & $\begin{array}{l}\text { Third Study } \\
\text { Visit }\end{array}$ & Delivery \\
\hline \multicolumn{5}{|l|}{ Biologic Samples } \\
\hline Maternal blood & 795 & 855 & 864 & 1023 \\
\hline Saliva & 453 & 822 & 778 & - \\
\hline Vaginal swabs & 212 & 791 & 588 & - \\
\hline Maternal buffy coat & 790 & 855 & 863 & 430 \\
\hline Placenta & - & - & - & 1047 \\
\hline Cord blood & - & - & - & 870 \\
\hline Cord blood buffy & - & - & - & 864 \\
\hline Amniotic fluid & - & - & - & 56 \\
\hline Infant buccal swab & - & - & - & 211 \\
\hline Cervical Imaging & 673 & 629 & 590 & $\mathrm{n} / \mathrm{a}$ \\
\hline Actigraphy & 737 & 806 & 696 & $\mathrm{n} / \mathrm{a}$ \\
\hline \multicolumn{5}{|l|}{ Surveys } \\
\hline Perceived Stress Scale & 1136 & 786 & 825 & $\mathrm{n} / \mathrm{a}$ \\
\hline Munich Chronotype Questionnaire & 1047 & 784 & 823 & $\mathrm{n} / \mathrm{a}$ \\
\hline Pittsburgh Sleep Quality Index & 1039 & 783 & 822 & $\mathrm{n} / \mathrm{a}$ \\
\hline Berlin Questionnaire & 984 & 781 & 823 & $\mathrm{n} / \mathrm{a}$ \\
\hline $\begin{array}{l}\text { Women's Health Initiative Insomnia Rating } \\
\text { Scale }\end{array}$ & 983 & 782 & 821 & $\mathrm{n} / \mathrm{a}$ \\
\hline Epworth Sleepiness Scale & 1035 & 783 & 821 & $\mathrm{n} / \mathrm{a}$ \\
\hline Intern. Restless Legs & 1032 & 783 & 821 & $\mathrm{n} / \mathrm{a}$ \\
\hline Kaiser Physical Activity & 1030 & 781 & 821 & $\mathrm{n} / \mathrm{a}$ \\
\hline Edinburgh Postnatal Depression & 1212 & 874 & 866 & $\mathrm{n} / \mathrm{a}$ \\
\hline Demographic/Med. Hist. & 1111 & 801 & 845 & $\mathrm{n} / \mathrm{a}$ \\
\hline Difficult Life Circumstances & $\mathrm{n} / \mathrm{a}$ & $\mathrm{n} / \mathrm{a}$ & $\mathrm{n} / \mathrm{a}$ & 654 \\
\hline NIH Diet Questionnaire & $\mathrm{n} / \mathrm{a}$ & $\mathrm{n} / \mathrm{a}$ & $\mathrm{n} / \mathrm{a}$ & 751 \\
\hline
\end{tabular}

A total of 1220 participants had live births.

A total of 63 participants provided consent to undergo uterine MRI and electrical mapping of the uterus 265 (electromyometrial imaging [EMMI]) at labor (Table 6). A total of 24 (17 low-risk, 7 high-risk) participants 
medRxiv preprint doi: https://doi.org/10.1101/2021.09.28.21264264; this version posted September 29, 2021. The copyright holder for this preprint (which was not certified by peer review) is the author/funder, who has granted medRxiv a license to display the preprint in perpetuity.

It is made available under a CC-BY-NC-ND 4.0 International license .

266 withdrew before the MRI for reasons such as delivery before MRI (8), lost contact (6), and patient/family 267 request to withdraw (6) (Table 6). A total of 25 participants in the low-risk group and 14 in the high-risk 268 group underwent MRI at least once during pregnancy (Table 7). In addition, 20 participants in the low-risk 269 group and 5 in the high-risk group underwent EMMI at labor (Table 6, 7). Reasons for missed EMMI 270 included: not notified by Labor and Delivery staff (3), delivered at offsite hospital (3), COVID-19 research 271 shut-down (2), and emergent cesarean section (2). Among those who underwent both MRI and EMMI, 272 none of the low-risk participants and two of the high-risk participants delivered preterm (Table 6).

Table 6: Project 3 Participants

274

275

\begin{tabular}{|c|c|c|c|c|}
\hline $\begin{array}{l}\text { Reasons for } \\
\text { Withdrawal }\end{array}$ & $\begin{array}{c}\text { Underwent } \\
\text { MRI }\end{array}$ & $\begin{array}{c}\text { Missed } \\
\text { EMMI }\end{array}$ & $\begin{array}{l}\text { Reasons for } \\
\text { Missed EMMI }\end{array}$ & $\begin{array}{c}\text { Underwent MRI } \\
\text { and EMMI }\end{array}$ \\
\hline $\begin{array}{l}\text { Delivered before } \\
\text { MRI }(7) \\
\text { Per request }(5) \\
\text { Lost contact }(4) \\
\text { Medical issue (1) }\end{array}$ & 25 & 5 & $\begin{array}{l}\text { Missed by L\&D } \\
\text { staff (3) } \\
\text { Delivered } \\
\text { precipitously (2) }\end{array}$ & $\begin{array}{c}20 \\
\text { (0 preterm, } \\
20 \text { term) }\end{array}$ \\
\hline $\begin{array}{l}\text { Lost contact (2) } \\
\text { Delivered before } \\
\text { MRI (1) } \\
\text { Lethal anomaly } \\
\text { (1) } \\
\text { Spontaneous } \\
\text { abortion (1) } \\
\text { Per request (1) } \\
\text { Social issues (1) }\end{array}$ & 14 & 9 & $\begin{array}{l}\text { Delivered at offsite } \\
\text { hospital (3) } \\
\text { COVID (2) } \\
\text { Emergency } \\
\text { cesarean (2) } \\
\text { Intrauterine Fetal } \\
\text { Demise (1) } \\
\text { Delivered } \\
\text { precipitously (1) }\end{array}$ & $\begin{array}{c}5 \\
\begin{array}{c}2 \text { preterm, } 3 \\
\text { term) }\end{array}\end{array}$ \\
\hline
\end{tabular}

EMMI, electromyometrial imaging; L\&D, Labor and Delivery; MRI, magnetic resonance imaging

Table 7. Project 3 procedures performed

\begin{tabular}{|l|c|c|c|c|c|}
\hline \multirow{2}{*}{ Group and procedure } & \multicolumn{5}{|c|}{ Timing } \\
\cline { 2 - 6 } & $\mathbf{2 4}$ weeks & $\mathbf{2 8}$ weeks & $\mathbf{3 2}$ weeks & $\mathbf{3 7}$ weeks & Labor \\
\hline Low Risk - Uterine MRI & - & - & - & 25 & \\
\hline High Risk - Uterine MRI & 14 & 9 & 9 & - & \\
\hline Low Risk - EMMI & - & - & - & - & 20 \\
\hline High Risk - EMMI & - & - & - & - & 5 \\
\hline
\end{tabular}

EMMI, electromyometrial imaging; MRI, magnetic resonance imaging

\section{DISCUSSION}

The Prematurity Research Cohort Study was a multi-faceted study aimed at identifying mechanisms underlying preterm birth. This report demonstrates the feasibility of conducting a longitudinal study in pregnant participants and maintaining high consent and retention rates. Moreover, we describe the rich data and specimen source now available for longitudinal studies of pregnancy. 
medRxiv preprint doi: https://doi.org/10.1101/2021.09.28.21264264; this version posted September 29, 2021. The copyright holder for this

preprint (which was not certified by peer review) is the author/funder, who has granted medRxiv a license to display the preprint in perpetuity.

It is made available under a CC-BY-NC-ND 4.0 International license .

283 The primary intent of establishing this cohort was to identify causes of, and develop novel diagnostics to

predict, preterm birth. Analyses of data from surveys, swabs, specimens, and imaging are ongoing for the

three projects. Specimens are also banked for future research to identify both risk factors and potential

biomarkers. The data and specimens we collected will be useful for addressing maternal and neonatal

health disparities. This is because over $50 \%$ of the participants were Black, and all lived in the St. Louis,

Missouri, area, where Black women have a $50 \%$ higher risk of preterm birth than white women (5).

\section{Feasibility}

Within three years, we enrolled 1260 participants who delivered, and we performed 6135 study visits

spanning all trimesters. Notably, 977 women attended three or more visits over the course of pregnancy.

We collected over 12,000 biological specimens with linked clinical and imaging data. Among the 1260

enrolled participants, 859 (68.1\%) participated in Project 1, Project 2, or both, the two projects open to all participants.

Study participants were more likely to comply with study procedures that could be timed with clinical

appointments or labs (e.g., blood draws, surveys done in waiting room or exam room). Fewer data and specimens were collected in the third trimester than in the first and second trimesters. In part, this was because some participants delivered before their third trimester study visit.

\section{Scientific Implications}

The Prematurity Research Cohort Study has generated a rich set of data and specimens that can be used

to test hypotheses pertaining to mechanisms of preterm birth and preventive targets. This dataset and specimen bank will also allow investigators to explore new questions regarding preterm birth, use imaging and biomarkers to assess preterm birth risk in the first trimester, and identify modifiable lifestyle factors that increase risk of preterm birth (6). Our cohort was predominantly those with the highest risk of preterm 
medRxiv preprint doi: https://doi.org/10.1101/2021.09.28.21264264; this version posted September 29, 2021. The copyright holder for this

preprint (which was not certified by peer review) is the author/funder, who has granted medRxiv a license to display the preprint in perpetuity.

It is made available under a CC-BY-NC-ND 4.0 International license .

309 African Americans (56\%) than the percentage in the US population (13.4\%) and had high rates of several

310 chronic conditions, which likely reflects the fact that the study was conducted at a tertiary care hospital.

312 Our experience reveals that pregnant patients are willing to participate in studies that require multiple 313 research visits, undergo serial transvaginal ultrasounds or MRI, answer extensive surveys, wear actigraphy 314 monitors, and collect timed saliva samples and other biological specimens beyond those required for 315 routine clinical care. Thus, other researchers should recognize that pregnant patients both can and should 316 be included in studies for obstetric and non-obstetric outcomes.

\section{Cost and Resource Utilization}

319 Conducting this study required extensive investments of time and financial resources. Full or partial 320 salaries were required for the 80 staff members, 31 trainees, and 23 faculty members who participated in 321 various aspects of the study. In addition, the study required abundant supplies (e.g., blood and placenta 322 sample collection tubes), dedicated freezer space, gift cards, and transportation arrangements. Such costs 323 and resources are important to consider in planning any longitudinal study in pregnancy. To reduce costs, 324 future studies could maximize use of web-based and social media tools to optimize recruitment and 325 retention $(13,14)$. Although we did not formally assess patient-reported acceptability of participating in the 326 cohort study, future work should investigate barriers and facilitators to patient adherence to multiple 327 research visits during pregnancy.

In summary, we report successful enrollment and follow-up of a large longitudinal cohort of pregnant patients. Additionally, we describe the substantial investments made by participants and research personnel to collect data and specimens. We are optimistic that their contributions will lead to new discoveries to improve the health of pregnant patients and their babies. 
medRxiv preprint doi: https://doi.org/10.1101/2021.09.28.21264264; this version posted September 29, 2021. The copyright holder for this preprint (which was not certified by peer review) is the author/funder, who has granted medRxiv a license to display the preprint in perpetuity. It is made available under a CC-BY-NC-ND 4.0 International license .

335 We thank the Prematurity Research Cohort Study participants for their invaluable contributions to preterm 336 birth research. We thank the research staff for their tireless efforts enrolling and following participants and 337 collecting and managing data and specimens. We thank Deborah Frank, PhD, Stephanie Pizzella, 338 Christine Kramer, and Jillian Ashley-Martin, PhD, for editorial comments and Anthony Bartley for graphical 339 assistance. This work was supported by a research grant from the March of Dimes Foundation and 340 institutional support from St. Louis Children's Hospital, Barnes-Jewish Hospital, and Washington University 341 in St. Louis School of Medicine. 


\section{REFERENCES}

344 1. Liu L, Oza S, Hogan D, Chu Y, Perin J, Zhu J, et al. Global, regional, and national causes of under-5 mortality in 2000-15: an updated systematic analysis with implications for the Sustainable Development Goals. Lancet. 2016;388(10063):3027-35.

2. Blencowe $\mathrm{H}$, Cousens S, Oestergaard MZ, Chou D, Moller AB, Narwal R, et al. National, regional, and worldwide estimates of preterm birth rates in the year 2010 with time trends since 1990 for selected countries: a systematic analysis and implications. Lancet. 2012;379(9832):2162-72.

3. Frey HA, Klebanoff MA. The epidemiology, etiology, and costs of preterm birth. Semin Fetal Neonatal Med. 2016;21(2):68-73.

4. Marlow N, Wolke D, Bracewell MA, Samara M, Group EPS. Neurologic and developmental disability at six years of age after extremely preterm birth. N Engl J Med. 2005;352(1):9-19.

5. Martin-Fairey CA, Zhao P, Wan L, Roenneberg T, Fay J, Ma X, et al. Pregnancy Induces an Earlier Chronotype in Both Mice and Women. J Biol Rhythms. 2019;34(3):323-31.

6. Lackritz EM, Wilson CB, Guttmacher AE, Howse JL, Engmann CM, Rubens CE, et al. A solution pathway for preterm birth: accelerating a priority research agenda. Lancet Glob Health. 2013;1(6):e32830.

7. Qu Y, Hu P, Shi J, Maslov K, Zhao P, Li C, et al. In vivo characterization of connective tissue remodeling using infrared photoacoustic spectra. J Biomed Opt. 2018;23(12):1-6.

8. Qu Y, Li C, Shi J, Chen R, Xu S, Rafsanjani H, et al. Transvaginal fast-scanning optical-resolution photoacoustic endoscopy. J Biomed Opt. 2018;23(12):1-4.

9. Wang $\mathrm{H}$, Wang $\mathrm{Y}$. Spatial-dependent regularization to solve the inverse problem in electromyometrial imaging. Med Biol Eng Comput. 2020;58(8):1651-65.

10. Wang H, Wu W, Talcott M, McKinstry RC, Woodard PK, Macones GA, et al. Electromyometrial imaging dataset of electromyograms and isochrone maps under deformation/electrical noise contaminations. Data Brief. 2020;28:105078.

11. Wang H, Wu W, Talcott M, McKinstry RC, Woodard PK, Macones GA, et al. Accuracy of electromyometrial imaging of uterine contractions in clinical environment. Comput Biol Med. 2020;116:103543.

12. Wu W, Wang H, Zhao P, Talcott M, Lai S, McKinstry RC, et al. Noninvasive high-resolution electromyometrial imaging of uterine contractions in a translational sheep model. Sci Transl Med. 2019;11(483).

13. Lawrie TA, Betran AP, Singata-Madliki M, Ciganda A, Hofmeyr GJ, Belizan JM, et al. Participant recruitment and retention in longitudinal preconception randomized trials: lessons learnt from the Calcium And Pre-eclampsia (CAP) trial. Trials. 2017;18(1):500.

14. Richiardi L, Baussano I, Vizzini L, Douwes J, Pearce N, Merletti F, et al. Feasibility of recruiting a birth cohort through the Internet: the experience of the NINFEA cohort. Eur J Epidemiol. 2007;22(12):831-7.

15. Cohen S, Kamarck T, Mermelstein R. A global measure of perceived stress. J Health Soc Behav. 1983;24(4):385-96.

16. Roenneberg T, Kuehnle T, Juda M, Kantermann T, Allebrandt K, Gordijn M, et al. Epidemiology of the human circadian clock. Sleep Med Rev. 2007;11(6):429-38.

17. Buysse DJ, Reynolds CF, 3rd, Monk TH, Berman SR, Kupfer DJ. The Pittsburgh Sleep Quality Index: a new instrument for psychiatric practice and research. Psychiatry Res. 1989;28(2):193-213.

18. Netzer NC, Stoohs RA, Netzer CM, Clark K, Strohl KP. Using the Berlin Questionnaire to identify patients at risk for the sleep apnea syndrome. Ann Intern Med. 1999;131(7):485-91.

19. Levine DW, Kaplan RM, Kripke DF, Bowen DJ, Naughton MJ, Shumaker SA. Factor structure and measurement invariance of the Women's Health Initiative Insomnia Rating Scale. Psychol Assess. 2003;15(2):123-36.

20. Johns MW. A new method for measuring daytime sleepiness: the Epworth sleepiness scale. Sleep. 1991;14(6):540-5.

21. Walters AS, LeBrocq C, Dhar A, Hening W, Rosen R, Allen RP, et al. Validation of the International Restless Legs Syndrome Study Group rating scale for restless legs syndrome. Sleep Med. 2003;4(2):121-32. 
medRxiv preprint doi: https://doi.org/10.1101/2021.09.28.21264264; this version posted September 29, 2021. The copyright holder for this preprint (which was not certified by peer review) is the author/funder, who has granted medRxiv a license to display the preprint in perpetuity.

It is made available under a CC-BY-NC-ND 4.0 International license .

396 22. Schmidt MD, Freedson PS, Pekow P, Roberts D, Sternfeld B, Chasan-Taber L. Validation of the 397 Kaiser Physical Activity Survey in pregnant women. Med Sci Sports Exerc. 2006;38(1):42-50.

398 23. Cox JL, Holden JM, Sagovsky R. Detection of postnatal depression. Development of the 10-item 399 Edinburgh Postnatal Depression Scale. Br J Psychiatry. 1987;150:782-6.

400 24. Curry MA, Campbell RA, Christian M. Validity and reliability testing of the Prenatal Psychosocial 401 Profile. Res Nurs Health. 1994;17(2):127-35.

402 25. Archer E, Hand GA, Blair SN. Validity of U.S. nutritional surveillance:National Health and Nutrition 403 Examination Survey caloric energy intake data, 1971-2010. PLoS One. 2013;8(10):e76632. 
medRxiv preprint doi: https://doi.org/10.110 /2021.09.28.21264264; this version posted September 29, 2021. The copyright holder for this preprint (which was not certified by peer revlew) isghe author/funder, who has granted medRxiv a license to display the preprint in perpetuity.
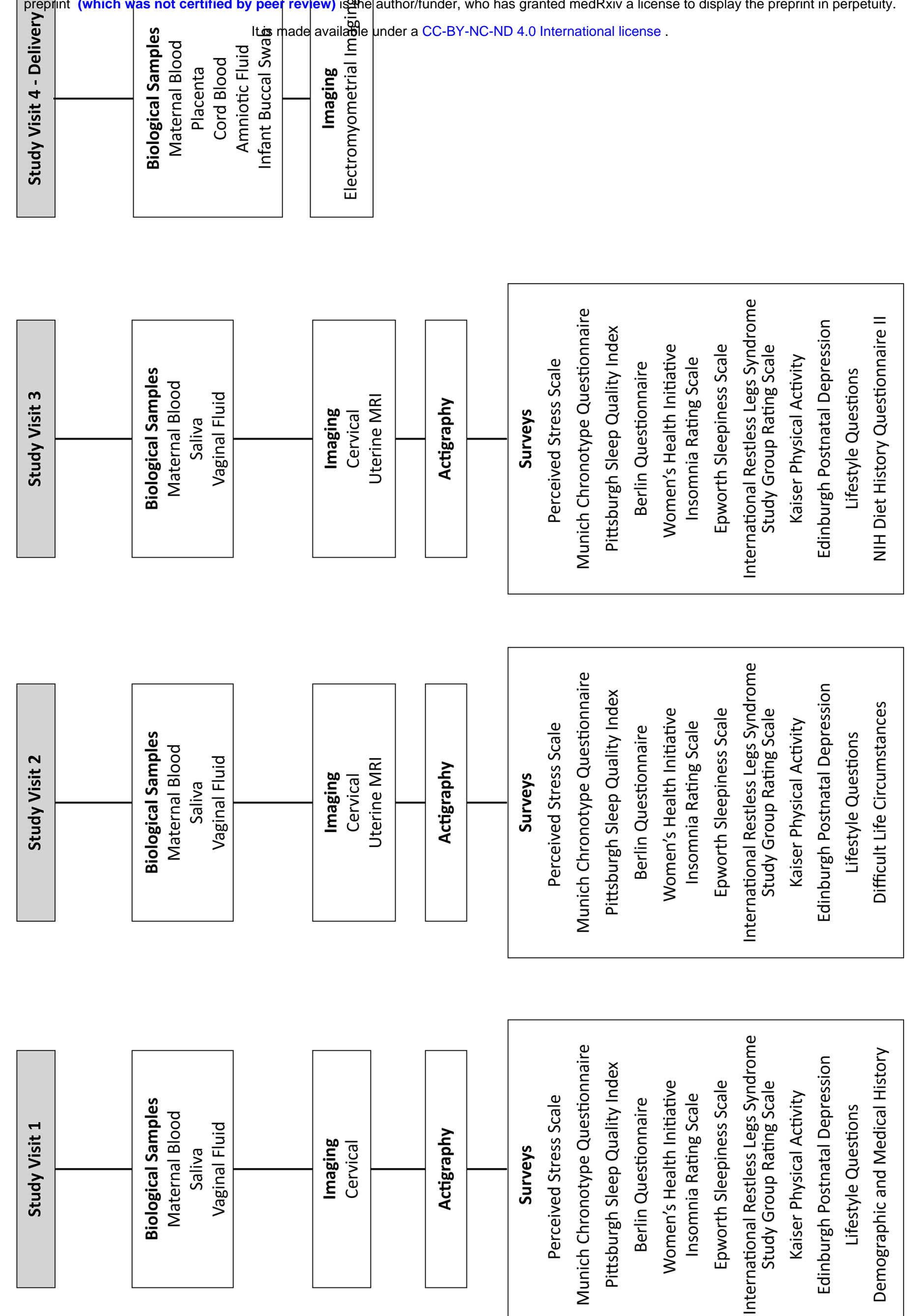
medRxiv prepriht doi:https://doi.org/10.1101/2021.09.28.21264264; this version posted September 29, 2021. The copyright holder for this preprint (whickwas ngig certified by peer review) is the author/funder, who has granted medRxiv a license to display the preprint in perpetuity.
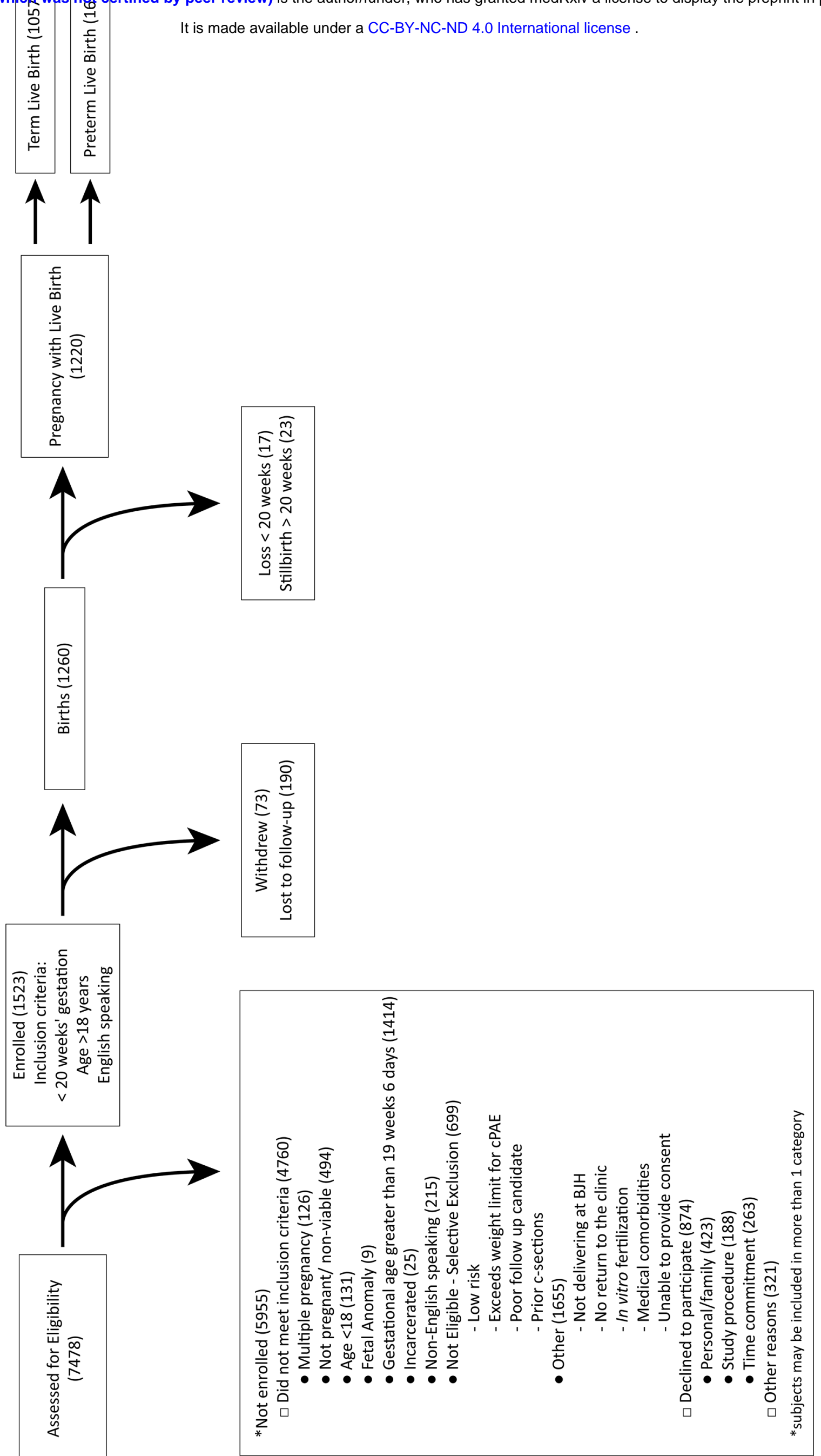
medRxiv preprint doi: https://doi.org/10.1101/2021.09.28.21264264; this version posted September 29, 2021. The copyright holder for this preprint (which was not certified by peer review) is the author/funder, who has granted medRxiv a license to display the preprint in perpetuity.

It is made available under a CC-BY-NC-ND 4.0 International license.

Supplemental Table 1: Sleep and lifestyle data surveys collected from participants

\begin{tabular}{|c|c|c|c|}
\hline Survey/Questionnaire & $\begin{array}{l}\text { Number of } \\
\text { questions }\end{array}$ & Example question & When implemented \\
\hline Perceived Stress Scale (15) & 10 & $\begin{array}{l}\text { In the last month, how often have you } \\
\text { been upset because of something that } \\
\text { happened unexpectedly? }\end{array}$ & Once per trimester \\
\hline $\begin{array}{l}\text { Munich Chronotype } \\
\text { Questionnaire (16) }\end{array}$ & 4 & $\begin{array}{l}\text { I have a regular work schedule (this } \\
\text { includes being a house wife or a house } \\
\text { husband). Y/N }\end{array}$ & Once per trimester \\
\hline $\begin{array}{l}\text { Pittsburgh Sleep Quality } \\
\text { Index (17) }\end{array}$ & 9 & $\begin{array}{l}\text { During the past month, how often have } \\
\text { you taken medicine to help you sleep } \\
\text { (prescribed or "over the counter")? }\end{array}$ & Once per trimester \\
\hline Berlin Questionnaire (18) & 10 & $\begin{array}{l}\text { Have you ever nodded off or fallen } \\
\text { asleep while driving a vehicle? }\end{array}$ & Once per trimester \\
\hline $\begin{array}{l}\text { Women's Health Initiative } \\
\text { Insomnia Rating Scale (19) }\end{array}$ & 5 & $\begin{array}{l}\text { In the past } 4 \text { weeks, did you wake up } \\
\text { several times at night? }\end{array}$ & Once per trimester \\
\hline $\begin{array}{l}\text { Epworth Sleepiness Scale } \\
(20)\end{array}$ & 8 & $\begin{array}{l}\text { How sleepy are you while sitting and } \\
\text { reading? }\end{array}$ & Once per trimester \\
\hline $\begin{array}{l}\text { International Restless Legs } \\
\text { Syndrome Rating Scale (21) }\end{array}$ & 5 & $\begin{array}{l}\text { Do you experience an urge to move or } \\
\text { unpleasant sensations that begin or } \\
\text { worsen during periods of rest or inactivity } \\
\text { such as laying or sitting? }\end{array}$ & Once per trimester \\
\hline $\begin{array}{l}\text { Kaiser Physical Activity } \\
\text { Survey (22) }\end{array}$ & 29 & $\begin{array}{l}\text { How many minutes a day do you usually } \\
\text { walk and/or bicycle to and from work, } \\
\text { school or errands? }\end{array}$ & Once per trimester \\
\hline $\begin{array}{l}\text { Edinburgh Postnatal } \\
\text { Depression Scale (23) }\end{array}$ & 10 & $\begin{array}{l}\text { I have been able to laugh and see the } \\
\text { funny side of things. (As much as } \\
\text { always, not quite so much now, definitely } \\
\text { not so much, not at all) }\end{array}$ & Once per trimester \\
\hline $\begin{array}{l}\text { Difficult Life Circumstances } \\
\text { (24) }\end{array}$ & 30 & $\begin{array}{l}\text { Are you having regular arguments or } \\
\text { conflicts with your present partner? }\end{array}$ & Second trimester \\
\hline $\begin{array}{l}\text { National Institutes of Health } \\
\text { Diet History Questionnaire II } \\
\text { (25) }\end{array}$ & 153 & $\begin{array}{l}\text { Over the past } 12 \text { months, how often did } \\
\text { you drink carrot juice? }\end{array}$ & $\begin{array}{l}\text { Third trimester or } \\
\text { within three months of } \\
\text { delivery }\end{array}$ \\
\hline $\begin{array}{l}\text { Demographic and medical } \\
\text { history questions }\end{array}$ & 11 & $\begin{array}{l}\text { At what age did you have your first } \\
\text { menstrual period? }\end{array}$ & First trimester \\
\hline Lifestyle questions & 12 & Do you currently smoke cigarettes? & Once per trimester \\
\hline
\end{tabular}

